\title{
A Research on Strategy Selling in Mobile Applications (With Special Reference to Instructional Applications)
}

\author{
X.Catherine Arputha Divya, S.Kothai
}

\begin{abstract}
The selling strategy may be a arrange developed for achieving the selling objectives of the organization. It provides a layout for attaining their selling objectives simply. The strategy is that the building block of a selling arrange. A selling strategy helps a company to arrange their scarce resources on the most effective opportunities so that they will increase their sales. Meantime mobile applications play an important role during this digital world. They increase the users by adapting the selling methods to extend their main objective (profit). During this study the training mobile apps area unit taken, to search out however these app developers area unit victimisation the MS to boost their business and increasing the numbers of users for these mobile apps. These applications area unit offered in google play store, apple store, black berry store to transfer the applications in their mobile. This study reveals that the developers victimisation totally different strategy to sustain their applications within the market.
\end{abstract}

Keywords: Developers, Mobile Applications (app), selling strategy (SS), Organization.

\section{INTRODUCTION}

The selling strategies are used to introduce the product in the market place. It is mainly used to achieve the selling objectives of the business / organization. The mobile applications are playing a vital role in the market. The app developers use many strategies to sell the app to the customers and to sustain in the competitive business world.

They use different ways to sell the applications, they are: May introduce a new blog page, Advertise in the websites, Play ad in between the other videos and use teasers.

The mobile applications which are mainly used in the android mobile, for this study the instructional applications are taken. The mainly used instructional applications are Kahoot, Additio, Class tree, Teach learn lead, and Slack.

The educators and students use these types of applications to improve their knowledge and to learn where ever they are. They provide many facilities to the users. They instruct the learners and give many innovative thinking to them.

This study reveals the selling strategy used by the developers to sustain in the market. And what are the strategies their mainly using to sell these applications in the market.

\section{OBJECTIVES OF THE STUDY}

To know the selling strategy of the developers

To find the various strategies used by the app developers Limitations of the study
It is used to find the selling strategies alone. Mainly used instructional applications only. Statistical tools used Percentage analysis Rank analysis

\section{REVIEW OF THE LITERATURE}

Evaluating app bundling strategy for selling mobile apps: an ambivalent perspective, jinlin wang, (2017), this study reveals that this study identifies the specific attributes of app-bundles using exploratory study. Second, this study addresses the challenges involved in examining bundles using ambivalence theory. In doing so, it characterizes attitude as positive and negative and treats them as separate constructs. Third, as called forth by previous studies, this study establishes the co-existence of positive attitude and negative attitude.

Mobile application market: A developer's perspective, adrain \& jan ondrus (2011), this study says that the newcomers have caused significant structural changes in the market by imposing and enforcing their own rules for the future of mobile application developments. The implications of these changes do not only concern the mobile network operators and mobile phone manufacturers but also bring additional opportunities and constraints for current mobile application developers.

\section{ANALYSIS AND INTERPRETATION \& RESULTS}

Table 1: Targeted Age group of the customers to sell the applications

\begin{tabular}{|l|l|l|l|}
\hline S.No & Particulars & $\begin{array}{l}\text { Number of } \\
\text { Respondent }\end{array}$ & Percentage \\
\hline 1 & below 20 & 9 & 9 \\
\hline 2 & 21 to 30 & 32 & 32 \\
\hline 3 & 31 to 40 & 30 & 30 \\
\hline 4 & 41 to 50 & 14 & 14 \\
\hline 5 & 51 to 60 & 15 & 15 \\
\hline & Total & 100 & 100 \\
\hline
\end{tabular}

Revised Manuscript Received on September 14, 2019.

Mrs.X.Catherine Arputha Divya, Assistant professor, (research scholar), Department of commerce CA \& BA, Sri Krishna Arts \& Science College, Coimbatore, Tamilnadu, India.(Email: Kathu777@gmail.com)

Dr.S.Kothai, Assistant professor, Department of commerce, Government Arts college, CBE, Tamilnadu, India.(Email: kothainat@hotmail.com) 
Interpretation: From the above table it is clear that $32 \%$ of the respondents are in the age group of 21 to 30 years, $30 \%$ of the respondents are in the age group of 31 to 40 years, $15 \%$ of the respondents are in the age group of 51 to 60 years, $14 \%$ of the respondents are in the age group of 41 to 50 years and only $9 \%$ of the respondents are in the age group of below 20 years. Majority of the respondents are between the age group of 21 to 30 years.

\section{Chart 1:}

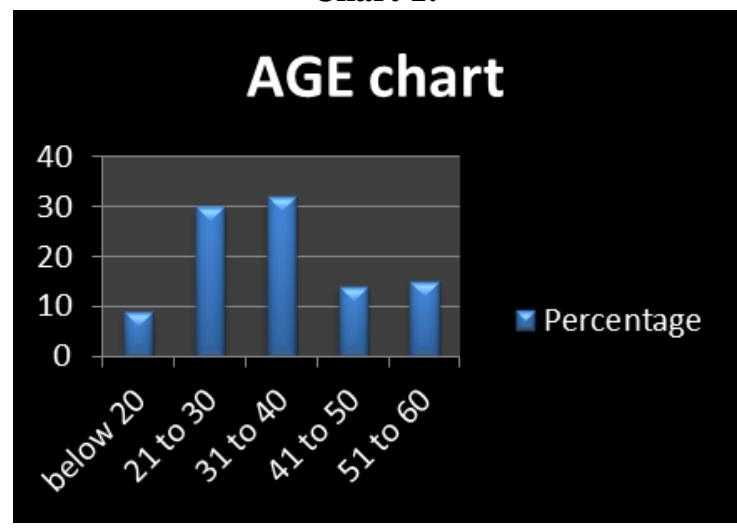

Table 2: The main app store used to sell the applications for free

\begin{tabular}{|l|l|l|l|}
\hline S.No & Particulars & $\begin{array}{l}\text { Number of } \\
\text { Respondent }\end{array}$ & Percentage \\
\hline 1 & Google app & 68 & 68 \\
\hline 2 & IPhone app & 32 & 32 \\
\hline & Total & 100 & 100 \\
\hline
\end{tabular}

Interpretation: From the above table it is clear that $68 \%$ of the respondents are says that google app store sell for free, and $32 \%$ of the respondents are says that IPhone app store sell for free . Majority of the respondents are saying google app store gives free applications.

Chart 2:

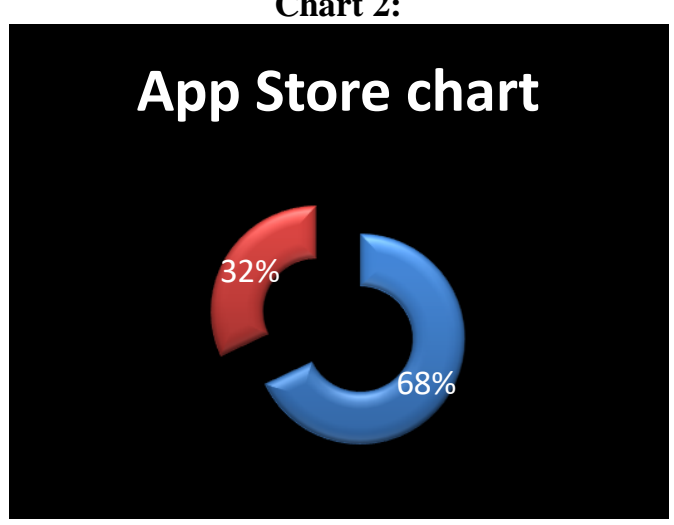

Table 3: Do you have a smart phone?

\begin{tabular}{|l|l|l|l|}
\hline S.No & Particulars & $\begin{array}{l}\text { Number of } \\
\text { Respondent }\end{array}$ & Percentage \\
\hline 1 & Yes & 72 & 72 \\
\hline 2 & No & 18 & 18 \\
\hline & Total & 100 & 100 \\
\hline
\end{tabular}

Interpretation: From the above table it is clear that $72 \%$ of the respondents are having smart phone, and only $18 \%$ of the respondents are having smart phone. Majority of the respondents are having smart phone.

Table 4: different selling strategies used by the app developers?

\begin{tabular}{|l|l|l|l|}
\hline S.N & Particulars & $\begin{array}{l}\text { Number } \\
\text { of } \\
\text { Respond } \\
\text { ent }\end{array}$ & $\begin{array}{l}\text { Percent } \\
\text { age }\end{array}$ \\
\hline 1 & $\begin{array}{l}\text { Uses video } \\
\text { to } \\
\text { advertise }\end{array}$ & 35 & 35 \\
\hline 2 & $\begin{array}{l}\text { Create a } \\
\text { blog page }\end{array}$ & 22 & 22 \\
\hline 3 & App stores & 15 & 15 \\
\hline 4 & $\begin{array}{l}\text { Friends } \\
\text { Advertise } \\
\text { ment in }\end{array}$ & 18 & 18 \\
\hline & $\begin{array}{l}\text { Total } \\
\text { TV }\end{array}$ & 100 & 100 \\
\hline
\end{tabular}

Interpretation: From the above table it is clear that $35 \%$ of the respondents are says that uses video to advertise, $22 \%$ of the respondents are says that creating a blog, $18 \%$ of the respondents are says that through app stores, $15 \%$ of the respondents are says that through freinds and only $10 \%$ of the respondents are says that through advertisement in TV. Majority of the respondents are says that through using video to advertise the applications.

Chart 3:

\section{selling strategies}

Rank Analysis 
Table 5: Rank the following mobile phone usage:

\begin{tabular}{|c|c|c|c|c|c|c|c|c|}
\hline \multirow[t]{2}{*}{ S.n } & \multirow[t]{2}{*}{ Factors } & \multicolumn{2}{|c|}{$\begin{array}{l}\text { Fully } \\
\text { aware }\end{array}$} & \multicolumn{2}{|c|}{$\begin{array}{l}\text { Partiall } \\
\text { aware }\end{array}$} & \multicolumn{2}{|c|}{$\begin{array}{l}\text { Not } \\
\text { aware }\end{array}$} & \multirow[t]{2}{*}{ Total } \\
\hline & & No & $\%$ & No & $\%$ & $\mathrm{No}$ & $\%$ & \\
\hline 1 & $\begin{array}{l}\text { Use } \\
\text { friendly }\end{array}$ & 66 & 66 & 24 & 24 & - & - & 100 \\
\hline 2 & Secured & 18 & 18 & 52 & 52 & 30 & 30 & 100 \\
\hline 3 & Privacy & 50 & 50 & 40 & 40 & 10 & 10 & 100 \\
\hline 4 & cost & 28 & 28 & 72 & 72 & - & - & 100 \\
\hline 5 & reliability & 32 & 32 & 56 & 56 & 12 & 12 & 100 \\
\hline
\end{tabular}

Interpretation: From the above table it is understood that $66 \%$ of the respondents are fully aware of the enhanced user friendly facility, $52 \%$ of the respondents are not aware of the secured facility, $50 \%$ of the respondents are fully aware of the privacy facility, $72 \%$ of the respondents are partially aware of the cost facility, $56 \%$ of the respondents are partially aware of the reliability facility .

Majority of the respondents are fully aware of the user friendly services.

\section{CONCLUSION}

The selling strategies are varies from product to product in the market, like wise the mobile applications instructional app are commonly used by the learners to learn more from their palm tabs. From the study its understood that the app developers uses many strategy to sustain their product in the market. They commonly uses video to advertise their application in mobile while using you tube and its users friendly apps. They providing it for free of cost to the users delight fullness. They fully satisfies the customers by introducing new technology in the mobiles app.

\section{REFERENCES}

1. https://www.emerald.com/insight/content/doi/10.1108/IT P-08-2015-0210/full/html

2. https://www.google.com/

3. http://www.sps186.org/schools/techservices/instructional _apps/?p=92012. 